\title{
Cytotoxic Effect of Propolis Nanoparticles on Ehrlich Ascites Carcinoma Bearing Mice
}

\author{
Jawharah A. Abdo1, Fahd M. Alsharif',3, Nivin Salah1, Om Ali Y. Elkhawaga1* \\ ${ }^{1}$ Division of Biochemistry, Department of Chemistry, Faculty of Science, Mansoura University, Mansoura, Egypt \\ ${ }^{2}$ Department of Pharmaceutics and Industrial Pharmacy, College of Pharmacy, Al-Azhar University, Assiut, Egypt \\ ${ }^{3}$ Department of Pharmaceutical Sciences, College of Pharmacy, University of Kentucky, Lexington, USA \\ Email: *dr.omaliyousef@gmail.com
}

How to cite this paper: Abdo, J.A., Alsharif, F.M., Salah, N. and Elkhawaga, O.A.Y. (2019) Cytotoxic Effect of Propolis Nanoparticles on Ehrlich Ascites Carcinoma Bearing Mice. Advances in Nanoparticles, 8, 55-70.

https://doi.org/10.4236/anp.2019.84005

Received: September 1, 2019

Accepted: October 8, 2019

Published: October 11, 2019

Copyright (c) 2019 by author(s) and Scientific Research Publishing Inc. This work is licensed under the Creative Commons Attribution International License (CC BY 4.0).

http://creativecommons.org/licenses/by/4.0/

\begin{abstract}
Background and objective Previous studies have demonstrated the anti-cancer effects of propolis. However, its use is limited because of its poor bioavailability. In the present study, the major objective was to improve propolis bioavailability using a nanosuspension formulation. The cytotoxic effect of propolis nanosuspension (PRO-NS) on the Ehrlich ascites carcinoma (EAC) in female Swiss albino mice was investigated in comparison to the free propolis. Materials and methods A propolis-loaded nanosuspension was formulated by applying solvent-antisolvent nano-precipitation technique. The prepared PRO-NS was characterized for average particle size, polydispersity index (PDI) and zeta potential. Also, the morphology of the nanosuspension particles was investigated using scanning electron microscopy (SEM). Moreover, PRO-NS cytotoxicity was tested using EAC bearing mice. The anticancer activity of Pro-NS was assessed by studying tumor volume, life span, viable and non-viable cell count, antioxidant, biochemical estimations and proliferation of EAC cells. Results The results revealed that propolis nanoparticles were relatively spherical in shape with rough surface. The tumor bearing mice treated with PRO-NS showed increased life span and inhibited tumor growth and the proliferation of EAC cells in comparison to the free propolis $(\mathrm{p}<0.01)$. Moreover, Pro-NS ameliorated the increase in serum aspartate transaminase (AST) and alanine transaminase (ALT) activities, IgM and the level of creatinine and urea after implantation of EAC cells. In addition, PRO-NS improved the SOD activity and glutathione content of liver and EAC cells. Furthermore, PRO-NS inhibited the formation of lipid peroxidation products (MDA) and total IgG in EAC tumor bearing mice. Conclusions Our results indicate that PRO-NS has a strong inhibitory activity against growth of tumors in comparison to free propolis. The anti-tumor mechanism may be mediated by preventing oxidative damage, immune-stimulation and induction of apoptosis.
\end{abstract}




\section{Keywords}

Propolis, Nanosuspension, Ehrlich Ascites Carcinoma Cells, Cytotoxicity, Immune-Stimulation, Cell Cycle

\section{Introduction}

Cancer is the most life-threatening disease. Cancer nowadays becomes a common disease due to the vast changes in the life style of people and its accounts for second major cause of mortality rate in the world. Chemotherapy and radiotherapy have many untoward side effects on healthy cells and the cancer cells are often drug-resistant [1]. High concentrations of reactive oxygen species (ROS) may induce oxidative damage to cell structures including lipids and membranes, proteins and nucleic acids; this damage is often referred to as oxidative stress and eventually leads to numerous chronic diseases, including atherosclerosis, cancer, diabetes and other degenerative diseases in humans [2]. ROS have previously been revealed to be involved in cancer initiation and promotion, and patients with neoplasms have demonstrated elevated malondialdehyde (MDA) concentrations [3].

Furthermore, several studies indicated that antioxidants inhibit free radical damage suggesting that treatment with a combination of antioxidants may be a potent adjunctive, preventive treatment for cancer [4]. Existing anti-cancer treatments including chemotherapeutic drugs, radiations, surgery are serving their purpose to some extent, but their side effects are much more than it, targeted treatment of disease [5].

Propolis (PRO) is a honey bee product that has a complex chemical composition. PRO has attracted much attention in recent years as a useful substance applied in medicine because of several biological and pharmacological properties [6] such as antimicrobial [7], antioxidant [8], anti-inflammatory [9], anticancer [10] and immunostimulant [11]. PRO antioxidant activity may be contributed to its high content of poly-phenolic composites such as flavonoids, tannins and terpenoids which have free radical scavenging activity [12]. However, PRO use is highly restricted due to its poor bioavailability [13].

Until now, propolis shows low bioavailability, which in turn, reduces propolis therapeutic effects. In 1987, propolis was tested in a clinical trial carried out by Hausen et al. at the dose of $3600 \mathrm{mg} /$ day. However, the concentrations of its metabolites in blood, as determined through HPLC method, were at nanomolar level [14] [15].

Hence, various approaches have been proposed to improve drug bioavailability.

Nano biotechnology is a promising field of nanoscience, which extends the horizon of nano-sized systems for various applications both in the field of biotechnology as well as in the field of Nanomedicine. Nanoparticles exhibit distinct 
physical and chemical properties compared to their bulk counterparts due to their small size and large surface area, besides high bioavailability, and biodegradability properties [16]. Moreover, nanoparticles enabled targeted drug delivery is found to be efficient for cancer treatment as nanoparticulate can cross some of the biological barriers and achieve therapeutic concentration in tumors even with less dosage of drug administration and spares the surrounding normal tissues from toxic effect [17].

Nanopropolis is a natural nano-material can be useful to medicine [18] and powerful antioxidant [19]. Moreover, it has been reported that the propolis in nanoform is more effective than propolis in terms of antibacterial and antifungal activity [20].

Therefore, the major goal of the present study is to improve propolis oral bioavailability via its use in nanosuspension form. The prepared nanosuspension will be characterized for particle size, size distribution and shape. Also, the antitumor, antioxidant activities and immunological changes as well as cell cycle of Ehrlich ascites carcinoma bearing mice treated with free Egyptian propolis and nanopropolis will be investigated.

\section{Materials and Methods}

\subsection{Chemicals}

Propolis was obtained from Egyptian honeybee keeper. Lecithin was purchased from Sigma Aldrich, St. Louis, MO, USA. DMSO was procured from Al-Nasr Chemicals Co. Cairo, Egypt. All other chemicals and reagents used in this study were of analytical grade and were purchased from Sigma Chemical Co. (St. Louis, MO, USA).

\subsection{Methods}

\subsubsection{Preparation of Propolis Nanosuspension (PRO-NS)}

Propolis nanosuspension formulation (PRO-NS) was prepared by solvent-antisolvent nanoprecipitation method according to methods of Thadkala et al. [21].

Briefly, dimethylsulfoxide (DMSO) and ethanol were used as solvents and lecithin was used as a surfactant to stabilize the formulated propolis nanosuspension. Briefly, the required amount of propolis ( $6.25 \mathrm{~g}$ in $25 \mathrm{~mL}$ vehicle) was accurately weighed and divided into two portions. Half amount of propolis was dissolved in DMSO (5\% v/v of total vehicle) and the other half was dissolved in 2 $\mathrm{mL}$ ethanol. Both solvents were used at $40^{\circ} \mathrm{C}$ and under sonication. Lecithin $(1 \%$ $\mathrm{w} / \mathrm{v}$ ) was dissolved in distilled water in $50 \mathrm{~mL}$ beaker. Water was used as the antisolvent. Then, propolis solutions were added drop wise into the antisolvent solution (water and lecithin) under constant stirring using magnetic stirrer. The product was kept under stirring for at least two hours to allow complete evaporation of ethanol. The volume was completed to $25 \mathrm{~mL}$ with distilled water and the produced NS was sonicated for $20-30 \mathrm{~min}$. 


\subsubsection{Characterization of PRO-NS}

The average size of PRO-NS was determined by dynamic light scattering using Zetasizer-Nano-ZSP (Malvern, UK). In addition, the shape of freeze-dried nanosuspension was investigated using SEM (JOEL-JSM-5400 LV scanning electron microscope, Japan).

\subsubsection{Ehrlich Ascites Carcinoma Cells}

Ehrlich ascites carcinoma cells (EAC) were initially supplied by the National Center Institute, Cairo, Egypt and maintained in female Swiss albino mice through serial intraperitoneal inoculation at 7 or 8 day intervals in our laboratory in an ascites form.

\subsubsection{Experimental Design}

All experiments were performed using adult female Swiss albino mice, with an average body weight of $25 \mathrm{~g}$ purchased from the animal house of the National Cancer Institute, Cairo University, Egypt. The mice were housed in steel mech cage and provided with commercial standard diet and tap water ad libitum.

A total of 60 Swiss albino mice were divided into 6 groups, 10 mice each, according to the following scheme: group 1, control (untreated) mice; groups 2 , treated with propolis extract $(4 \mathrm{mg} / \mathrm{kg}$ consequently) daily by an intragastric tube for 9 days; groups 3 treated with PRO-NS extract ( $4 \mathrm{mg} / \mathrm{kg}$ consequently) daily by an intragastric tube for 9 days; groups 4 , mice inoculated intraperitoneally with $1 \times 10^{6}$ EAC tumor cells; groups 5 , mice were treated by $4 \mathrm{mg} / \mathrm{kg}$ propolis extract after 24 hours of implantation of $1 \times 10^{6} \mathrm{EAC}$ tumor cells; groups 6 mice were treated by $4 \mathrm{mg} / \mathrm{kg}$ PRO-NS mice were treated by $4 \mathrm{mg} / \mathrm{kg}$. After two days of the last treatment, the animals were sacrificed by decapitation. Ascetic fluid, blood and livers were immediately obtained after the animals were sacrificed. Blood samples allowed clotting for 10 to $15 \mathrm{~min}$, centrifuged and the serum was separated and was kept in $-70^{\circ} \mathrm{C}$. An accurately weighed piece of each of livers was homogenized in ice-cold $0.9 \%$ saline using a Teflon pestle connected to a homogenizer motor. The homogenates were adjusted at a concentration of $5 \%(\mathrm{w} / \mathrm{v})$, centrifuged at $5000 \mathrm{rpm}$ for 30 minutes at $4^{\circ} \mathrm{C}$ to remove cell debris and nuclei. The resulting supernatant was used for biochemical analysis.

\subsubsection{Determination of Viability and Volume of EAC Cells}

The cell viability of living EAC cells was tested following the trypan Blue exclusion technique was checked according to the method of Boyse et al. [22]. The volume of harvested EAC cells was estimated directly after collection from mice at times.

\subsubsection{Determination of Survival Time}

Three groups of mice $(\mathrm{n}=12$ each) were implanted with Ehrlich carcinoma cells. One of them was daily treated propolis extract and third group treated PRO-NS ( $4 \mathrm{mg} / \mathrm{kg}$ consequently) daily by an intragastric tube for 9 days. 


\subsubsection{Enzyme Assay}

Serum samples were obtained by centrifugation at $3000 \mathrm{r} / \mathrm{min}$ for $20 \mathrm{~min}$ and stored at $-20^{\circ} \mathrm{C}$ for biochemical analysis. creatinine, urea, aspartate aminotransferase (AST), alanine aminotransferase (ALT) and total proteins were estimated in serum using commercial kits (Biodiagnostic Company for Laboratory Services, Giza, Egypt) according to the manufacturer instructions. Also, after collection of EAC cells from the ascetic fluids by centrifugation (i.e. $1000-2000 \mathrm{rpm}$ for 10 minutes at $4^{\circ} \mathrm{C}$ ). Cell pellet and liver were homogenized in a cold buffer and the levels of glutathione (GSH, non-enzymatic antioxidant). Thiobarbituric acid reactive substances (TBARS), an index of lipid peroxidation and superoxide dismutase (SOD, antioxidant enzyme) were measured using assay kits (Biodiagnostic Company for Laboratory Services, Giza, Egypt) according to the manufacturer's instructions.

\subsubsection{Measurement of Total IgG and IgM}

Total serum IgG and IgM were measured by enzyme-linked immunosorbent assay (ELISA) with a mouse IgG ELISA quantification kit and a mouse IgM ELISA quantification kit, respectively (Bethyl Laboratories Inc., Montgomery, TX).

\subsubsection{Flow Cytometry}

Single cell suspension was prepared from fresh biopsy samples in RPMI-1640 medium. Cells were permeabilized with Triton X-100 followed by staining using propidium iodide as a DNA-specific fluorochrome. Flow cytometric analysis was performed on FACS Calibur Flow Cytometer, Becton Dickinson, Heidelberg, Germany; excitation of fluorescence occurred at $488 \mathrm{~nm}$ (15 mw air cooled argon ion lazer) and optimized for linear fluorescence single detection with the use of fluorochrome-labeled microspheres (DNA Checked Beads, Coulter Corp.). Data analysis was performed with DNA analysis software program using a linear S-fit method for cell cycle kinetic analysis. Interpretation of DNA histograms was analyzed using cytoloic software (Coulter Corp.) [23].

\subsubsection{Statistical Analysis}

All data are expressed as mean \pm SD. One-way analysis of variance (ANOVA) followed by a Tukey's test was used to assess significant differences among all groups using GraphPad Prism Software 5 (LaJolla, CA, USA). P values were considered statistically significant at $\mathrm{P}<0.05$.

\section{Results}

\subsection{Characterization of Propolis-Nanosuspension (PRO-NS)}

\subsubsection{Particle Size, Size Distribution (Polydispersity Index, PDI) and Zeta Potential}

The particle size, PDI and zeta potential values of PRO-NS are presented in Table 1, Figure 1. As can be seen, the PRO-NS formulation showed average particle size of $185.27 \pm 26.44 \mathrm{~nm}$ with narrow size distribution as indicated by the low PDI value. In addition, PRO-NS had a zeta potential value of $-37.97 \pm 1.30$ $\mathrm{mV}$. 
Table 1. Characterization of formulation of propolis nanosuspension.

\begin{tabular}{ccc}
\hline Size $(\mathrm{nm})$ & PDI & Zeta potential $(\mathrm{mV})$ \\
\hline $185.27 \pm 26.44$ & $0.215 \pm 0.042$ & $-37.97 \pm 1.30$ \\
\hline
\end{tabular}

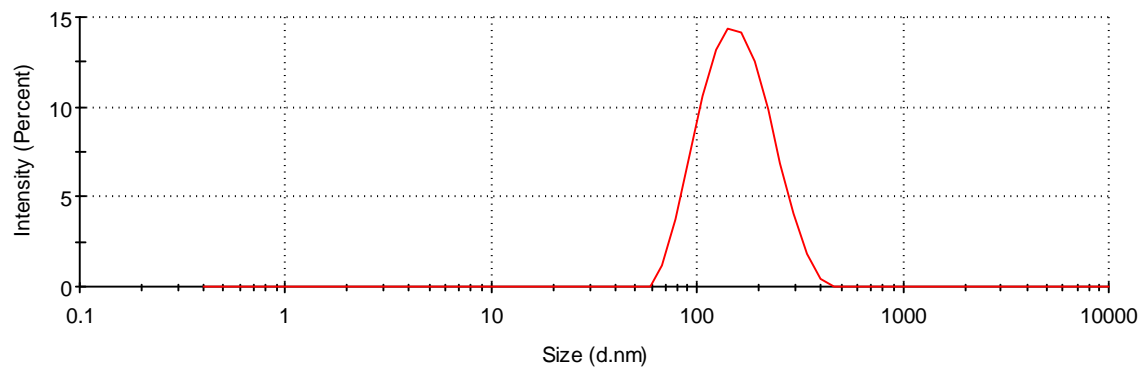

Figure 1. Size distribution by intensity of PRO-NS.

\subsubsection{Scanning Electron Microscopy (SEM)}

The morphology of PRO-NS with SEM is shown in Figure 2. The SEM images showed that the targeted nanosuspension was roughly spherical shapes. Moreover, no particles aggregation was noticed during the samples microscopic observation.

Results are given as mean $\pm \mathrm{SD}(\mathrm{n}=3)$. SD: standard deviation, PDI: polydispersity index.

\subsection{Antitumor Activity of Propolis and PRO-NS}

Figure 3 shows the effect of propolis and PRO-NS on the survival rate of EAC-beard mice. The results demonstrate that the survival time increased from 14 days for untreated tumor-bearing mice to 50 and 41 days for tumor bearing mice treated with PRO-NS or free propolis respectively. However, at the same time, the volume and viability of EAC cells were significantly $(\mathrm{p}<0.001)$ reduced EAC -beard mice treated with propolisor PRO-NS respectively (Figure 4 and Figure 5). Moreover, the present results showed that the treatment of EAC-beard mice with propolis or PRO-NS leads to a significant decrease in the activity of serum ALT, AST and the levels of creatinine, urea and MDA (Table 2) compared to that of untreated EAC-beard mice. A significant elevation in the levels of hepatic and ascetic GSH and SOD were obtained in EAC-beard mice treated with propolis or PRO-NS respectively compared to untreated mice (Table 3 and Table 4). The effect of oral administration of propolis and PRO-NS on the hepatic and ascetic MDA levels were illustrated on Table 3 and Table 4. A significant decrease in their level in EAC-beard mice treated by propolis and PRO-NS. On the other hand, a highly significant decrease in serum IgM content after transplantation of EAC cells $(21.67 \pm 0.88)$ compared to control groups $(62.67 \pm 2.006)$. Administration of propolis or PRO-NS into EAC-beard mice inhibits the decrease in serum IgM observed in saline-treated tumor-bearing mice $(31.33 \pm 0.88)$ and $(34.33 \pm 1.202)$ respectively. Transplantation of EAC cells caused a highly significant increase (53\%) in total serum IgG 
with respect to the untreated tumor bearing mice. Treatment of EAC-beard mice with propolis or PRO-NS caused decrease in total serum IgG by $28 \%$ and $31 \%$ respectively when compared with the content of total serum IgG in untreated tumor bearing mice (Figure 6, Figure 7). Figure 8 shows EAC cells proliferation measures by flow cytometer to analyze the component of the cell cycle. It is evident that EAC cells from PRO-NS (Figure 8(c)) or free propolis (Figure 7(b)) treated mice exhibited significantly higher G0/G1\% and lower S-phase \% and $\mathrm{G} 2 / \mathrm{M} \%$ as compared with that obtained from untreated mice in addition, subG1 aneuploid peak is observed in propolis and PRO-NS treated mice histogram and this peak is closely associated both with the DNA degradation and morphological changes typical of apoptosis.

Table 2. Effect of propolis and PRO-NS on serum AST, ALT, urea and creatinine levels.

\begin{tabular}{ccccc}
\hline $\begin{array}{c}\text { Parameters } \\
\text { Groups }\end{array}$ & ALT (U/L) & AST (U/L) & Urea (mg/dl) & $\begin{array}{c}\text { Creatinine } \\
(\mathrm{mg} / \mathrm{dl})\end{array}$ \\
\hline $\begin{array}{c}\text { Normal } \\
\text { saline-treated } \\
\text { Normal }\end{array}$ & $53 \pm 5.292$ & $50.00 \pm 2.082$ & $46.2 \pm 3.126$ & $0.87 \pm 0.04410$ \\
$\begin{array}{c}\text { PRO-NS-treated } \\
\quad \text { Normal }\end{array}$ & $50.33 \pm 3.283^{\mathrm{NS}}$ & $49.50 \pm 1.708^{\mathrm{NS}}$ & $49.00 \pm 2.483^{\mathrm{NS}}$ & $0.845 \pm 0.021^{\mathrm{NS}}$ \\
$\begin{array}{c}\text { Propolis-treated } \\
\text { EAC-beard mice }\end{array}$ & $130.3 \pm 9.223^{* * *}$ & $132.5 \pm 13.77^{* *+}$ & $76.25 \pm 4.270^{* * *}$ & $1.35 \pm 0.0645^{* *}$ \\
$\begin{array}{c}\text { PRO-NS Treated } \\
\text { EAC-beard mice }\end{array}$ & $85.00 \pm 6.455^{+++}$ & $67.25 \pm 3.301^{+++}$ & $45.75 \pm 5.865^{+++}$ & $0.912 \pm 0.0427^{+++}$ \\
$\begin{array}{c}\text { Propolis Treated } \\
\text { EAC-beard mice }\end{array}$ & $91.00 \pm 5.788^{++}$ & $81.00 \pm 3.536^{++}$ & $49.57 \pm 4.589^{++}$ & $0.985 \pm 0.0473^{++}$ \\
\hline
\end{tabular}

The results are expressed as mean $\pm \mathrm{SD}$. The mean is average of 6 value. ${ }^{* * *}$ Significant $(\mathrm{P}<0.001)$ compared to saline-treated normal mice.,+++++ Significant $(\mathrm{P}<0.01,0.001$ respectively) compared to saline-treated tumor bearing mice. NS: not significant compared to saline-treated normal mice.

Table 3. Effect propolis and PRO-NS on liver SOD, MDA, GSH in different groups of mice.

\begin{tabular}{cccc}
\hline $\begin{array}{c}\text { Parameter } \\
\text { Groups }\end{array}$ & SOD (U/gm) & GSH $(\mathrm{mg} / \mathrm{g})$ & MDA (nmol/g) \\
$\begin{array}{c}\text { Normal } \\
\text { saline treated } \\
\text { Normal } \\
\text { PRO-NS treated } \\
\quad \text { Normal } \\
\text { propolis treated }\end{array}$ & $53.00 \pm 2.799$ & $39.25 \pm 4.603$ & $49.25 \pm 4.498$ \\
$\begin{array}{c}\text { EAC-beard mice } \\
\text { PRO-NS-treated } \\
\text { EAC beard mice } \\
\text { Propolis-treated } \\
\text { EAC beard mice }\end{array}$ & $13.43 \pm 1.400^{* * *}$ & $14.42 \pm 1.328^{* * *}$ & $122.5 \pm 11.24^{* * *}$ \\
\hline
\end{tabular}

The results are expressed as mean $\pm \mathrm{SD}$. The mean is average of 6 value. ${ }^{* *}$ Significant $(\mathrm{P}<0.001)$ compared to saline-treated normal mice.,+++++ Significant $(\mathrm{P}<0.01,0.001$ respectively) compared to saline-treated tumor bearing mice. NS: not significant compared to saline-treated normal mice. 
Table 4. Effect of propolis and PRO-NS on SOD, MDA and GSH levels in Ehrlich ascites carcinoma cells.

\begin{tabular}{cccc}
\hline $\begin{array}{c}\text { Parameters } \\
\text { Groups }\end{array}$ & $\begin{array}{c}\text { MDA } \\
\text { (nmol/mg protein) }\end{array}$ & $\begin{array}{c}\text { GSH } \\
(\mathrm{nmol} / \mathrm{mg} \text { protein })\end{array}$ & $\begin{array}{c}\text { SOD } \\
(\mathrm{nmol} / \mathrm{mg} \text { protein })\end{array}$ \\
\hline EAC-beard mice & $52.25 \pm 1.931$ & $8.925 \pm 0.9673$ & $4.100 \pm 1.082$ \\
$\begin{array}{l}\text { PRO-NS-treated } \\
\text { EAC-beard mice }\end{array}$ & $20.43 \pm 1.440+++$ & $16.23 \pm 1.598++$ & $12.43 \pm 1.840++$ \\
$\begin{array}{l}\text { Propolis-treated } \\
\text { EAC-beard mice }\end{array}$ & $28.65 \pm 3.943++$ & $13.68 \pm 0.6824+$ & $10.05 \pm 0.8995+$ \\
\hline
\end{tabular}

The results are expressed as mean \pm SD. The mean is average of 6 value.,,++++++ : Significant $(\mathrm{P}<0.05, \mathrm{P}$ $<0.01, \mathrm{P}<0.001)$ compared to saline-treated tumor bearing mice.

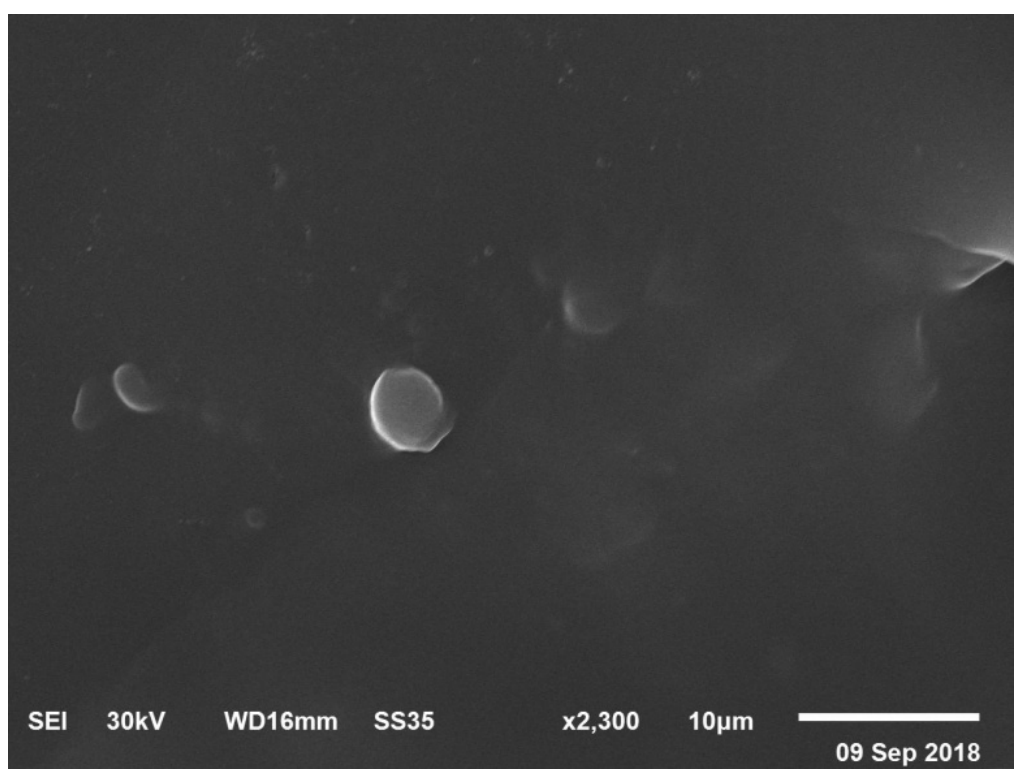

Figure 2. SEM micrograph of propolis nanosuspension.

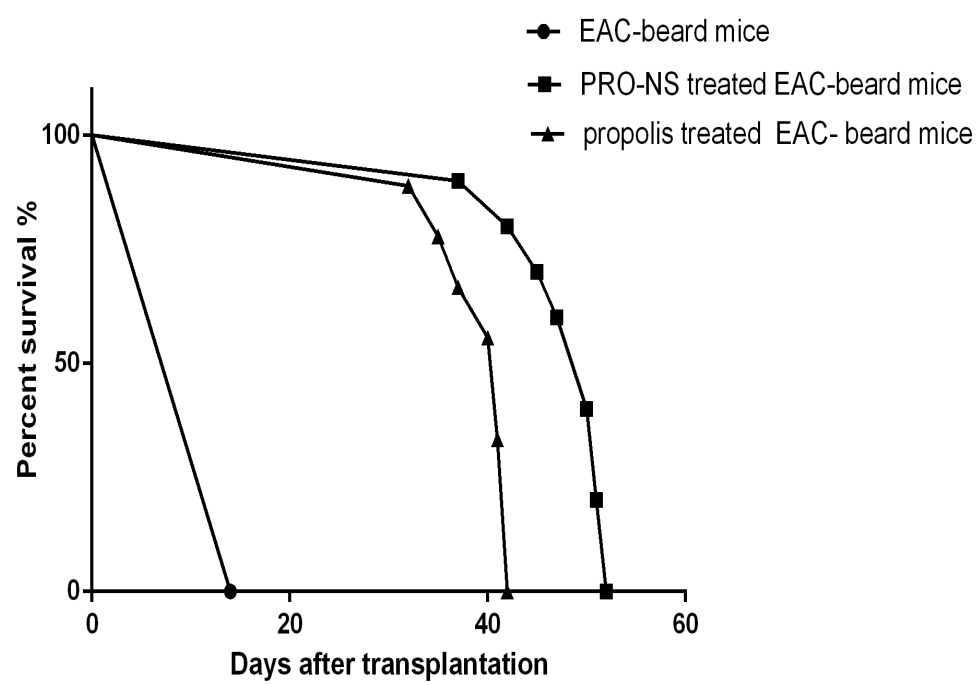

Figure 3. Survival of Swiss albino mice after IP implantation of Ehrlich ascites carcinoma cells. Mice were given daily IP doses of either propolis or PRO-NS for 9 days. 


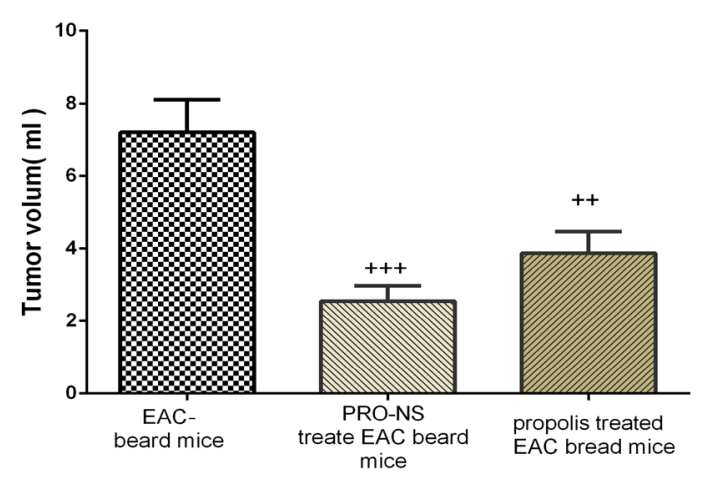

Groups

Figure 4. Effect of propolis and PRO-NS on tumor volume in tumor bearing mice.

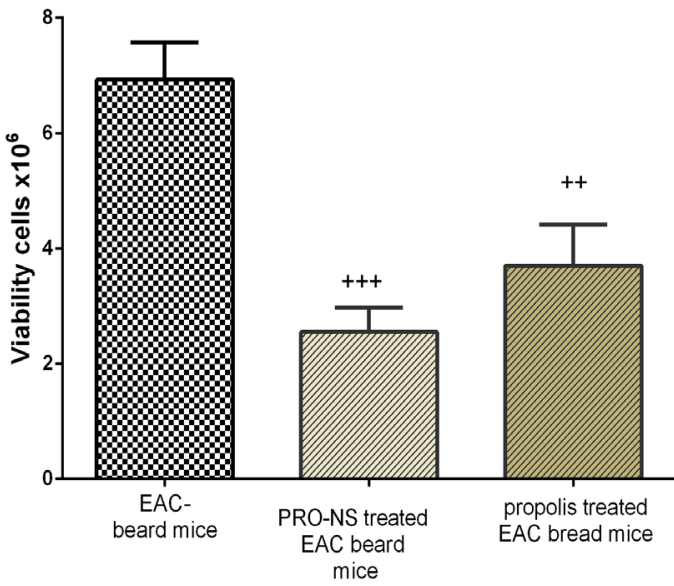

Groups

Figure 5. Effect of propolis and PRO-NS on viability of EAC cells in vivo.

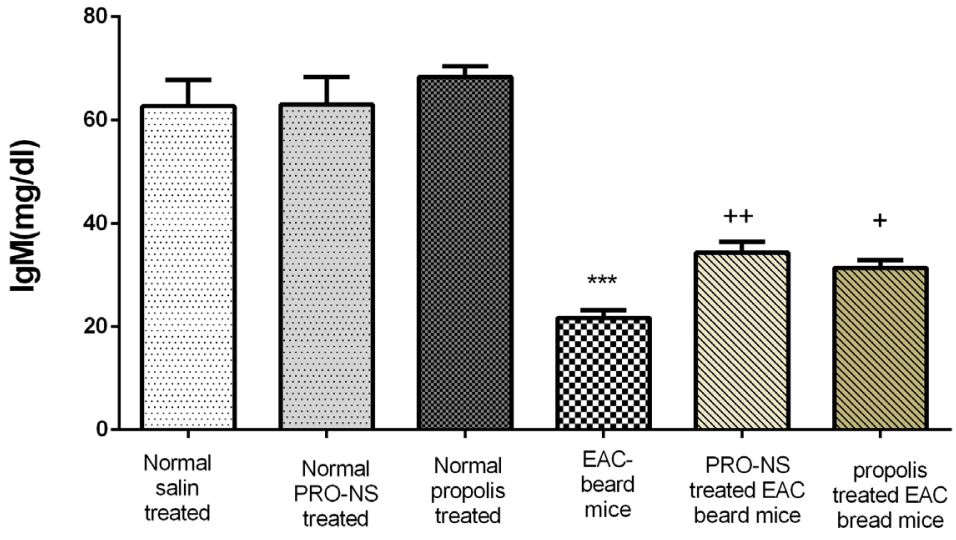

\section{Groups}

Figure 6. Effect of propolis and PRO-NS on serum IgM in different group of mice. 


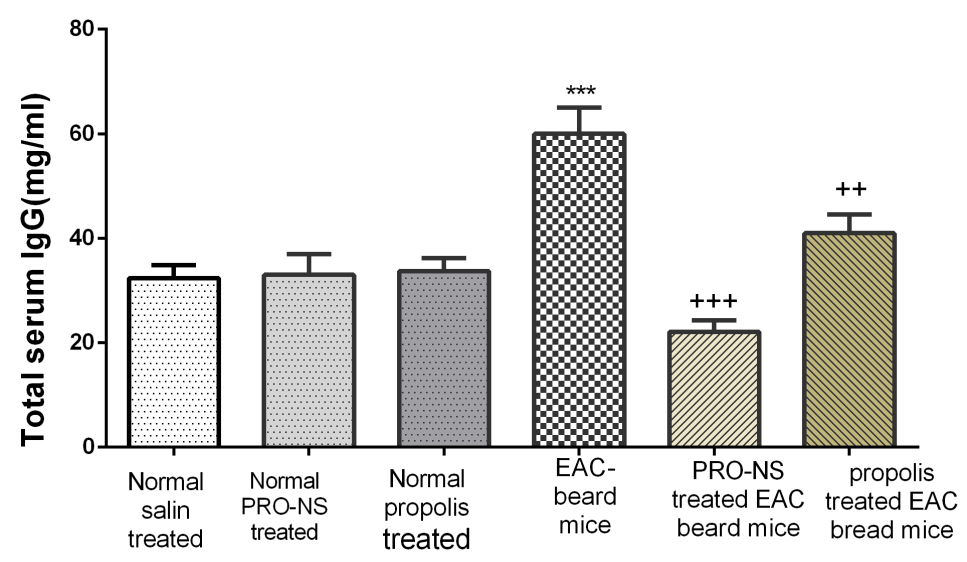

Groups

Figure 7. Effect of propolis and PRO-NS on total serum IgG in different group of mice.

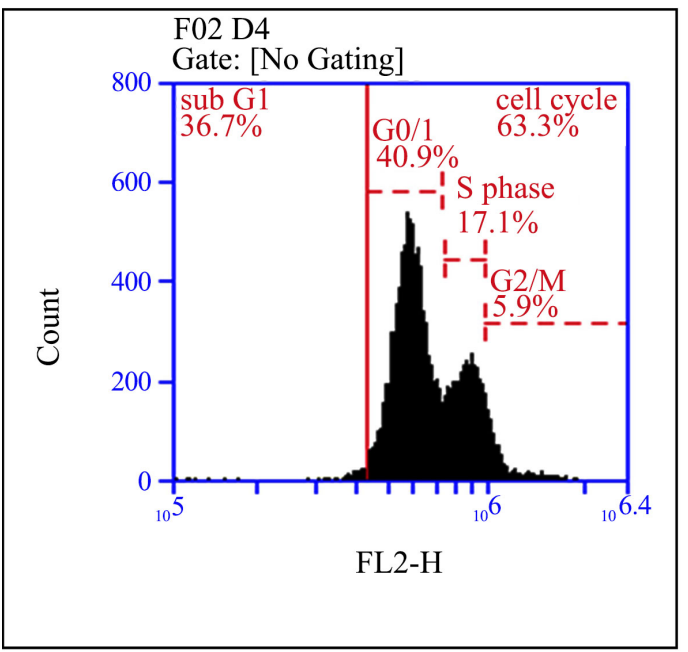

(a)

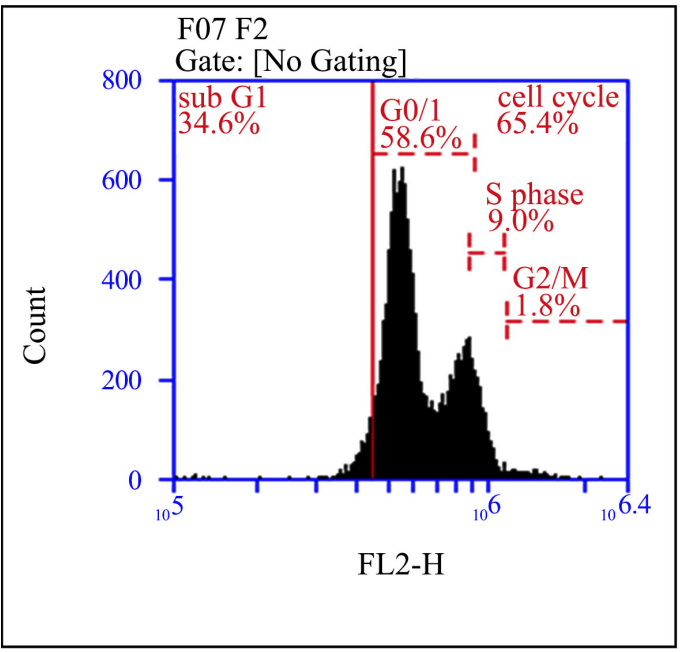

(b) 


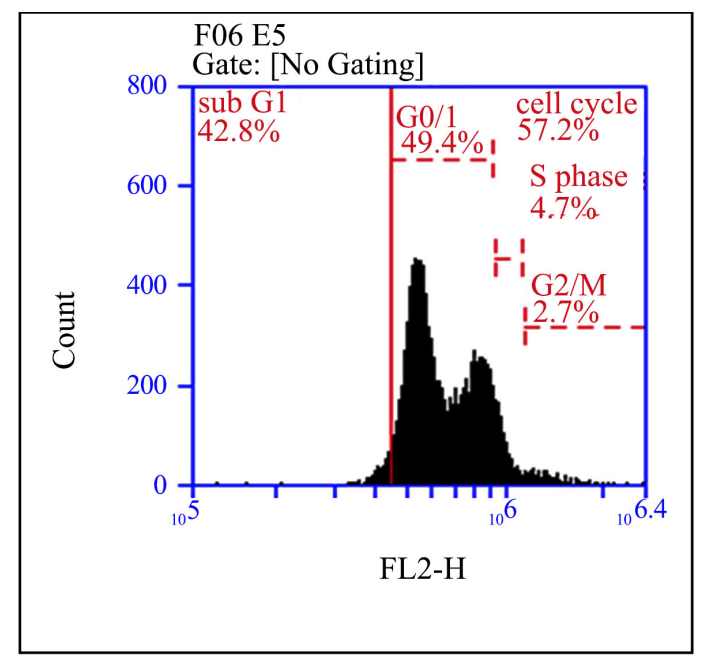

(c)

Figure 8. DNA histogram obtained from Erich ascites carcinoma cells (EAC). (a) histogram of EAC cells isolated from saline treated mice; (b) histogram of EAC cells isolated from propolis treated mice; (c) histogram of EAC cells isolated from PRO-NS treated mice.

\section{Discussion}

Cancer remains to be one of the most common causes of death. Thus, one of the goals of cancer research has been and continues to be the discovery of natural and synthetic products for cancer prevention and treatment. Among many of the natural products that have been shown to exhibit antimutagenic activity as ascorbic acid [24] and others exhibiting antitumor activity like gossypol, a spermatoxin inhibits growth of different cell lines [25].

The present study aimed to investigate one of the naturally occurring products, propolis. It has been reported that PRO exhibited anticancer activity. However, propolis suffers a major drawback because of its reduced solubility and hence, poor bioavailability.

Therefore, nanosuspension form of PRO was proposed to overcome these problems. It was found that mean particle size of PRO-NS was in the nano-range with low PDI. In addition, zeta potential of the prepared PRO-NS was high. This high zeta potential value accounts for nanosuspension stability and hence, prevents particle aggregation. Also, the high negative charge helps cell internalization which leads to increased cellular content of the nanoformulation. SEM revealed that particles of the nanosuspension were spherical in shape with no aggregations. This is more likely due to the negative charges on the surface of particles as evidenced by zeta potential measurement. These charges prevent particles aggregation via repelling each other.

This study was mainly focused on investigating the cytotoxic effects of PRO in nanosuspension form. To this end, the antitumor activity of PRO-NS was tested by measuring the viability of EAC cells, tumor volume and survival time in tumor bearing mice. in comparison to free propolis treatment. The enhanced 
cytotoxicity of propolis encapsulated in particle may relate to its increased penetration into the EAC cells.

The antitumor activity of PRO and PRO-NS was reflected by the highly significant increases in life span of host animals and decreases in both value and viability of EAC cells after treatment with $4 \mathrm{mg}$ propolis or PRO-NS/Kg body weight respectively compared with the corresponding findings in saline-treated tumor-bearing mice (Figure 3).

With regard to the biochemical studies, most biochemical methods used for early diagnosis of cancer are based on the analysis of blood for specific biochemical markers and abnormal enzymes activities. It is well known that most liver and kidney diseases are caused by toxic agents. These diseases and damage are accompanied by elevations in serum level of creatinine and urea. The present results indicate that the treatment of EAC bearing mice with propolis or PRO-NS showed a marked reduction in the creatinine and urea levels. The decreased levels of creatinine agree with previous work [26] [27] [28]. Moreover, these results are in consistent with observed significant decreases in tumor volume and the viability of propolis or PRO-NS treated tumor bearing mice compared to saline-treated tumor bearing mice. The treatment of normal mice with propolis or PRO-NS resulted in a significant decrease in serum ALT and AST activity compared with its activity in untreated normal mice. The implantation of EAC cells into the mice caused a significant reduction in serum AST and ALT activity compared to its activity in normal ones. In contrast, serum AST and ALT activity of tumor-bearing mice treated with propolis or PRO-NS were found to be unchanged. These findings are in agreement with observed elevations in serum activities of AST, ALT and elevation of serum urea of Silveira et al. [28] and Gaskill et al. [29]. This result may be attributed to the possibility that propolis or PRO-NS can prevent tumor growth and at the same time prevent the infilteration of the tumor cells through the abdominal cavity (which causes ascites as noticed in many tumor-bearing mice). In addition, no significant hepatotoxicity was observed by propolis or PRO-NS in treated control group. Since the liver is a sensitive target towards extra hepatic tumors, therefore, alterations in the activities of serum hepatic enzymes and urea concentrations are expected to occur. On the other hand, a significant decrease in hepatic enzymes and urea in propolis and PRO-NS-treated tumor bearing group compared to untreated group was observed. This result is in agreement with the findings of Kanbur et al. [30] who attributed the similar changes to tumor growth.

The results of the present study indicated that the activity of liver SOD was reduced in saline-treated tumor bearing mice. The modulated effect as manifested by propolis and PRO-NS which is indicated by the significant increase in SOD activity in tumor-bearing mice could be attributed to the success of this mode of treatment in decreasing the number of EAC cells. It is suggested that elevated levels of SOD and GSH may be due to increased SOD and GSH genes expression in liver and EAC cells obtained from propolis and PRO-NS-treated 
mice and may counteract the effects induced by oxidative stress in EAC-bearing mice when compared with normal control animals. Conversely, the lipid peroxides concentration measured as malonidialdehyde (MDA) was inhibited in the EAC-beard mice treated with propolis and PRO-NS may exert its role through the enhancement of antioxidant system. These results are confirmed by the previous findings that reported the importance of propolis or PRO-NS as an antioxidant agent [31], who reported that propolis extract increase the free radical scavenging activity through its effect on GSH level and SOD activity. Therapeutic activities of propolis mainly depend on the presence of flavonoids. Flavonoids exhibit a wide range of biological effects including free radical scavenging and antioxidant activities [32] Since propolis has been used empirically for centuries and it was always mentioned as an immunomodulatory agent. In this study, therefore, the effect of propolis and PRO-NS were examined on the production of IgG and IgM in EAC bearing mice, which are responsible for the primary and secondary immune responses. Propolis and PRO-NS administration decreased the production of IgG in EAC bearing mice peripheral blood. However, their administration increased the production of IgM in EAC bearing mice peripheral blood. These results are in agreement with the findings of Takagi et al. [33] who reported that administration of propolis increased IgG production in the early to middle term in rats. Propolis has an interferon (IFN)-like activity to induce and activate macrophages and T-lymphocytes, which may explain the difference between the two results [34]. Activated macrophages secrete cytokines (IL-1, IL-6, IL-12 and TNF- $\alpha$ ), and activate T-cells. Furthermore, activated T-cells secrete IFN- $\gamma$ which inhibits differentiation to antibody-producing B cells. Suzuki et al. [35] reported that propolis increased IFN- $\gamma$. Therefore, the cell-mediated immune response is activated, while the humoral immune response is in turn suppressed [36]. As observed in this study, the IFN-like activity of propolis stimulated the cell mediated immune response of macrophages and T-cells, while it suppressed the humoral immune response and reduced antibody production. The present flow cytometric study supported these findings and showed that PRO-NS not only retarded EAC cells growth by delaying their progression from G0/G1 to the DNA synthetic phase of the cell cycle but also significantly slowed DNA synthesis during the cell cycle in PRO-NS or free propolis treated mice in comparison with that of untreated mice (Figure 8). Considering these cell cycle results with reduced viability, tumor volume, ALT, AST, creatinine, urea, MDA, IgG and increased life span, SOD activity, GSH, IgM, it appeared that PRO-NS might be due to the activation of immune system of tumor-bearing mice treated with PRO-NS more than free propolis and produced apoptotic cells which might be phagocytosed either by macrophages or by adjacent viable cells.

\section{Conflicts of Interest}

The authors declare no conflicts of interest regarding the publication of this paper. 


\section{References}

[1] Hayat, M.J., Howlader, N., Reichman, M.E. and Edwards, B.K. (2007) Cancer Statistics, Trends, and Multiple Primary Cancer Analyses from the Surveillance, Epidemiology, and End Results (SEER) Program. Oncologist, 12, 20-37. https://doi.org/10.1634/theoncologist.12-1-20

[2] Yeh, C.C., Hou, M.F., Tsai, S.M., Lin, S.K., Hsiao, J.K., Huang, J.C., Wang, L.H., Wu, S.H., Hou, L.A., Ma, H. and Tsai, L.Y. (2005) Superoxide Anion Radical, Lipid Peroxides and Antioxidant Status in the Blood of Patients with Breast Cancer. Clinica Chimica Acta, 361, 104-111. https://doi.org/10.1016/j.cccn.2005.05.002

[3] Duračková, Z. (2010) Some Current Insights into Oxidative Stress. Physiological Research, 59, 459-469.

[4] Rahman, M., Alam, M., Choi, Y. and Yoo, J. (2017) Anticancer Activity and Antioxidant Potential of Aponogeton undulatus against Ehrlich ascites Carcinoma Cells in Swiss Albino Mice. Oncology Letters, 14, 3169-3176.

https://doi.org/10.3892/ol.2017.6484

[5] Boca, S.C., Potara, M., Gaabudean, A.M., Juhem, A., Baldeet, P.L. and Astilean, A. (2011) Chitosan Coated Triangular Silver Nano Particles as a Novel Class of Biocompatible, Highly Effective Photothermal Transducers for in Vitro Cancer Cell Therapy. Cancer Letters, 311, 137-140. https://doi.org/10.1016/j.canlet.2011.06.022

[6] Toreti, V.C., Sato, H.H., Pastore, G.M. and Park, Y.K. (2013) Recent Progress of Propolis for Its Biological and Chemical Compositions and Its Botanical Origin. Evidence-Based Complementary and Alternative Medicine, 2013, Article ID: 697390. https://doi.org/10.1155/2013/697390

[7] Shokri, H., Katiraee, F., Fatahinia, M. and Minooeianhaghighi, M.H. (2017) Chemical Composition and Antifungal Potential of Iranian Propolis against Candida Krusei Strains. Journal of Apicultural Research, 56, 581-587. https://doi.org/10.1080/00218839.2017.1371534

[8] Yang, X., Wang, X., Chen, X.-Y., Ji, H.-Y., Zhang, Y. and Liu, A.-J. (2018) Pinocembrin-Lecithin Complex: Characterization, Solubilization, and Antioxidant Activities. Biomolecules, 8, 41. https://doi.org/10.3390/biom8020041

[9] Funakoshi-Tago, M., Okamoto, K., Izumi, R., Tago, K., Yanagisawa, K., Narukawa, Y., Kiuchi, F., Kasahara, T. and Tamura, H. (2015) Antiinflammatory Activity of Flavonoids in Nepalese Propolis Is Attributed to Inhibition of the IL-33 Signaling Pathway. International Immunopharmacology, 25, 189-198.

https://doi.org/10.1016/j.intimp.2015.01.012

[10] Turan, I., Demir, S., Misir, S., Kilinc, K., Mentese, A., Aliyazicioglu, Y. and Deger, O. (2015) Cytotoxic Effect of Turkish Propolis on Liver, Colon, Breast, Cervix and Prostate Cancer Cell Lines. Tropical Journal of Pharmaceutical Research, 14, 777-782. https://doi.org/10.4314/tjpr.v14i5.5

[11] Sforcin, J.M. (2007) Propolis and the Immune System: A Review. Journal of Ethnopharmacology, 113, 1-14. https://doi.org/10.1016/j.jep.2007.05.012

[12] El-Naggar, S.A., Alm-Eldeen, A.A., Germoush, M.O., El-Boray, K.F. and Elgebaly, H.A. (2015) Ameliorative Effect of Propolis against Cyclophosphamide-Induced Toxicity in Mice. Pharmaceutical Biology, 53, 235-241. https://doi.org/10.3109/13880209.2014.914230

[13] Seven, P.T., Seven, I., Baykalir, B.G., Murtu, S.I. and Salem, A.Z. (2018) Nanotechnology and Nano-Propolis in Animal Production and Health: An Overview. Italian Journal of Animal Science, 17, 921-930. 
https://doi.org/10.1080/1828051X.2018.1448726

[14] Hausen, B.M., Wollenweber, E., Senff, H. and Post, B. (1987) Propolis Allergy: (I). Origin, Properties, Usage and Literature Review. Contact Dermatitis, 17, 163-177. https://doi.org/10.1111/j.1600-0536.1987.tb02699.x

[15] Curti, V., Zaccaria, V., Sokeng, T., Jorel, A., Dacrema, M., Masiello, I., Mascaro, A., D'Antona, G. and Daglia, M. (2019) Bioavailability and in Vivo Antioxidant Activity of a Standardized Polyphenol Mixture Extracted from Brown Propolis. International Journal of Molecular Sciences, 20, 1250. https://doi.org/10.3390/ijms20051250

[16] Vaidyanathan, R., Kalishwaralal, K., Gopalram, S. and Gurunathan, S. (2009) Nanosilver: The Burgeoning Therapeutic Molecule and Its Green Synthesis. Biotechnology Advances, 27, 924-937. https://doi.org/10.1016/j.biotechadv.2009.08.001

[17] Kothai, S. and Jayanthi, B. (2014) Anti-Cancer Activity of Silver Nano-Particles Bio-Synthesized Using Stingless Bee Propolis (Tetragonula iridipennis) of Tamilnadu. Asian Journal of Biomedical and Pharmaceutical Sciences, 4, 30-37. https://doi.org/10.15272/ajbps.v4i40.654

[18] Sahlan, M., Dienayati, D., Hamdi, D., Zahra, S., Hermansyah, H. and Chulasiri, M. (2017) Encapsulation Process of Propolis Extract by Casein Micelle Improves Sunscreen Activity. Makara Journal of Technology, 21, 1-6. https://doi.org/10.7454/mst.v21i1.3072

[19] Petrov, P.D., Tsvetanov, C.B., Mokreva, P., Yoncheva, K., Konstantinov, S., Trusheva, B., Popova, M. and Bankova, V. (2016) Novel Micellar Form of Poplar Propolis with High Cytotoxic Activity. RSC Advances, 6, 30728-30731. https://doi.org/10.1039/C6RA03577A

[20] Afrouzan, H., Amirinia, C., Mirhadi, S., Ebadollahi, A., Vaseji, N. and Tahmasbi, G. (2012) Evaluation of Antimicrobial Activity of Propolis and Nanopropolis against Staphylococcus aureus and Candida albicans. African Journal of Microbiology Research, 6, 421-425. https://doi.org/10.5897/AJMR11.1183

[21] Thadkala, K., Nanam, P.K., Rambabu, B., Sailu, C. and Aukunuru, J. (2014) Preparation and Characterization of Amorphous Ezetimibe Nanosuspensions Intended for Enhancement of Oral Bioavailability. International Journal of Pharmaceutical Investigation, 4, 131. https://doi.org/10.4103/2230-973X.138344

[22] Boyse, E.A., Old, L.J. and Chouroulinkov, I. (1964) Cytotoxic Test for Determination of Mouse Antibody. Methods in Medical Research, 10, 39-47.

[23] Baisch, H., Gohde, W. and Lindn, W. (1975) Analysis of PCP-Data to Determine the Fraction of Cells in the Various Phases of Cell Cycle. Radiation and Environmental Biophysics, 12, 31-39. https://doi.org/10.1007/BF02339807

[24] Perrone, G., Hideshima, T., Ikeda, H., Okawa, Y., Calabrese, E., Gorgun, G., Santo, J., Cirstea, D., Raje, N., Chauhan, D., Baccarani, M., Cavo, M. and Anderson, K.C. (2009) Ascorbic Acid Inhibits Antitumor Activity of Bortezomib in Vivo. Leukemia, 23, 1679-1686. https://doi.org/10.1038/leu.2009.83

[25] Li, L., Li, W., Kim, Y.-H. and Lee, Y.W. (2013) Chlorella vulgaris Extract Ameliorates Carbon Tetrachloride-Induced Acute Hepatic Injury in Mice. Experimental and Toxicologic Pathology, 65, 73-80. https://doi.org/10.1016/j.etp.2011.06.003

[26] Li, Y.J., Lin, J.L., Yang, C.W. and Yu, C.C. (2005) Acute Renal Failure Induced by a Brazilian Variety of Propolis. American Journal of Kidney Diseases, 46, 125-129. https://doi.org/10.1053/j.ajkd.2005.08.028

[27] Newairy, A., Salama, A., Hussien, H. and Yousef, M. (2009) Propolis Alleviate Alu- 
minium-Induced Lipid Peroxidation and Biochemical Parameters in Male Rats. Food and Chemical Toxicology, 47, 1093-1098. https://doi.org/10.1016/j.fct.2009.01.032

[28] Silveira, M., Teles, F. Berretta, A., Sanches, T., Rodrigues, C., Seguro, A. and Andrade, L. (2019) Effects of Brazilian Green Propolis on Proteinuria and Renal Function in Patients with Chronic Kidney Disease: A Randomized, Double-Blind, Placebo-Controlled Trial. BMC Nephrology, 20, 140.

https://doi.org/10.1186/s12882-019-1337-7

[29] Gaskill, C., Miller, L., Mattoon, J., Hoffmann, W., Burton, S., et al. (2005) Liver Histopathology and Liver Serum Alanine Aminotransferase and Alkalinephosphatase Activities in Epileptic Dogs Receiving Phenobarbital. Veterinary Pathology, 42, 147-160. https://doi.org/10.1354/vp.42-2-147

[30] Kanbur, M., Eraslana, G. and Silicib, S. (2008) Antioxidant Effect of Propolis against Exposure to Propetamphos in Rats. Ecotoxicology and Environmental Safety, 72, 909-915. https://doi.org/10.1016/j.ecoenv.2007.12.018

[31] Padmavathi, R., Senthilnathan, P., Chodon, D. and Sakthisekaran, D. (2006) Therapeutic Effect of Paclitaxel and Propolis on Lipid Peroxidation and Antioxidant System in 7,12-Dimethylbenz (a)anthracene-Induced Breast Cancer in Female Sprague Dawley Rats. Life Sciences, 24, 2820-2825. https://doi.org/10.1016/j.lfs.2005.11.005

[32] Alm-Eldeen, A.A., Basyony, M.A., Elfiky, N.K. and Ghalwash, M.M. (2017) Effect of the Egyptian Propolis on the Hepatic Antioxidant Defense and Pro-Apoptotic p53 and Anti-Apoptotic bcl2 Expressions in Aflatoxin B1 Treated Male Mice. Biomedicine \& Pharmacotherapy, 87, 247-255. https://doi.org/10.1016/j.biopha.2016.12.084

[33] Takagi, Y., Choi, I., Yamashita, T., Nakamura, T., Suzuki, I., Hasegawa, T., Oshima, M. and Gu, Y. (2005) Immune Activation and Radioprotection by Propolis. The American Journal of Chinese Medicine, 33, 231-240. https://doi.org/10.1142/S0192415X05002886

[34] Rininger, J.A., Kickner, S., Chigurupati, P., McLean, A. and Franck, Z. (2000) Immunopharmacological Activity of Echinacea Preparations Following Simulated Digestion on Murine Macrophages and Human Peripheral Blood Mononuclear Cells. Journal of Leukocyte Biology, 68, 503-510.

[35] Suzuki, I., Hayashi, I., Takaki, T., Groveman, D.S. and Fujimiya, Y. (2002) Antitumor and Anticytopenic Effects of Aqueous Extracts of Propolis in Combination with Chemotherapeutic Agents. Cancer Biotherapy and Radiopharmaceuticals, 17, 553-562. https://doi.org/10.1089/108497802760804781

[36] Paganelli, R., Scala, E., Aiuti, F. and Fiorilli, M. (1998) B-Cell Help by Tc2 Cells. Immunology Today, 19, 142. https://doi.org/10.1016/S0167-5699(98)80013-3 